\title{
COMPARISON OF COMPETITIVENESS AND BUSINESS PERFORMANCE IN THE VISEGRÁD GROUP SINCE THE EU ACCESSION: A QUANTITATIVE ANALYSIS
}

\section{Bolotov, I.}

The goal of this paper is to analyze main changes in the business performance - as in part of the overall competitiveness - of the Visegrád Group, i.e. Czech Republic, Slovak Republic, Poland and Hungary, in the last ten years, 2004-2014, based on Pearson correlation, Chow and Granger Causality tests. The business performance in the Visegrád Group is defined with the help of five indicators: business density, value added per business entity, investment in fixed capital per business density, inward foreign direct investment stock per business entity and exports of goods and services per business entity. The author finds that the business performance, and hence the business environment, in the Visegrád Group has diverged since EU accession with the exception of internationalization indicators, which indicates the necessity for managers to adjust to the specifics in each particular country.

Keywords: Competitiveness; business environment; Central and Eastern Europe; Visegrád Group. JEL classification: M21, 010, O52.

\section{Introduction}

The Visegrád Group, also called the Visegrád Four (V4), is since 1993 an association of four advanced Central and Eastern European countries (CEEC) - Czech Republic, Slovakia, Hungary and Poland - inside the European Union (EU 28), promoting economic, energy and military cooperation, as well as strengthening European integration among its members (Hnát, Stuchlíková, Bič, 2006). Since the Visegrád Group were the most competitive CEEC ranked as 30s-60s in the world in 2014-2015 (World Economic Forum, 2015), this paper aims to compare the main changes in the crucial aspect of their competitiveness, the business performance, in the last ten years, 2004-2014, i.e. after their accession to the EU, with a focus on the Visegrád Four as a whole and on mutual comparison between countries, employing tools of quantitative analysis (see the methodological section). The paper is based on this hypothesis $(\mathrm{H})$ : the business performance inside the Visegrád Group is converging and is moving towards the EU 28's average.

\section{State of Research on the Topic}

The topic of competitiveness / business performance in the Visegrád Group has been examined in a few research papers. Bluhm, Martens, and Trappmann (2011) point to the role of elites in the early stages of business environment formation in Poland and Hungary in 
the 1990s. Brewster and Bennett (2010) stress that perceptions of business culture in Bulgaria, Romania and the Visegrád Group remain mostly negative among both the local managers and expatriate ones. Hamplová (2011) and Belás et al. (2014) compare the business conditions in the Czech Republic and Slovak Republic, assessing both of them as adequate. Kalowski (2010), Urban (2010), Kinčaková (2013), Němečková (2013), Kmet’ (2014), Šebestová, Adámek, and Cooney (2014) and Zuzek (2014) conduct countryspecific studies on each Visegrád Group member with country-specific conclusions. Markowicz (2014) attempts to model the lifespan of an average Polish business entity. Nečadová and Soukup (2013) and Paličková (2013) examine competitiveness in the Visegrád Group. Finally, Jiránková and Bolotov (2015) perform a complex study on changes in the business environment in the Visegrád Group since 1995. Bolotov (2015) employs more sophisticated econometrical methods and extends the comparison and methodology to Eastern Europe, based among others, on the findings of Baláž et al. (2011) and Anisimova and Brenchagova (2012).

\section{Methods Employed in the Paper}

Business performance in the Visegrád Group is defined, in this paper, with the help of five indicators, as suggested in Jiránková and Bolotov (2015): 1) business density (total number of business units per 1 thousand of economically active population) (abbreviated as BD); 2) value added per business entity (VApB); 3) domestic investment in fixed capital (gross fixed capital formation) per business density (GFCFpB); 4) inward foreign direct investment stock per business entity (FDIpB); and 5) exports of goods and services per business entity $(\mathrm{XpB})$. With $\mathrm{BD}$ being the main indicator of the business environment, VApB and GFCFpB indicate economic performance, and FDIpB and XpB - internationalization of an average business entity; one of the indicators of national competitiveness (World Economic Forum, 2015).

To quantify the results of the paper, the author employs (Pearson) correlation coefficients and two statistical tests, the Chow test and the Granger causality test to find important dates and causalities between the indicators of the business performance and the level of economic development (real gross domestic product per capita, abbreviated as RGDPpc) and price level in the EU 28 terms (the comparative price level, CPL, EU $28=100)$.

The Chow test (Chow, 1960) is an F-test calculated from the sums of squared residuals of the three ordinary least square models (OLS), which are formed by dividing the examined time series $y_{t}$ into two subsets with the help of a customary (structural) breaking point: set $\mathrm{A}$, set $\mathrm{B}$ and the pooled time series. The test examines whether the coefficients of OLS models for A and B are different, i.e. whether the breaking point is statistically significant.

The Granger causality test (Granger, 1969) is a Wald F-test (Wald, 1943) between a dependent variable $y_{t}$ and lagged values of a regressor $x_{t}$ under the condition of stationarity of $y_{t}, x_{t}$. The model has the following form under the assumption of equal number of lags $k$ :

$$
y_{t}=\alpha_{0}+\mathrm{A} \sum_{j=1}^{j=k} y_{t-j} \Gamma \sum_{j=1}^{j=k} x_{t-j}+\varepsilon_{t}
$$


where $\alpha_{0}$ and A and $\Gamma$ matrices are regression coefficients, $x_{t}$ - the regressor, and $\varepsilon_{t}$ are residuals of the model. The test determines whether development of $y_{t}$, can be forecasted with lagged values of $x_{t}$ (if $x_{t}$ Granger causes $y_{t}$ ). In this paper, first differences $\Delta y_{t}$ and $\Delta x_{t}$ are considered since its necessary requirement is stationarity (short memory of both time series).

Data are acquired from the national statistical offices (for the total number of businesses; data published under the national standards) of the four countries and from Eurostat (for all economic indicators; data published under the ESA2010 and BPM6 manuals), which insured their comparability: Eurostat does not specify any breaks in series (exports are taken as gross cross-border trade, according to the valid Eurostat definition, 'branding' not included). Due to the small length of time series (11 observations) and interest of the author in the long-term development, i.e. in the trend, de-trending is not performed, which is reflected in the (Pearson) correlation analysis.

\section{Comparison of Business Performance Indicators in the Visegrád Group}

The development of competitiveness and of the business environment in the Visegrád Group after 2004 corresponded with its integration into the EU and into the world economy, becoming part of the regional and global value chains (GVCs) (Bolotov, Čajka, Gajdušková, 2013): the analysis presented below shows growth in the number of business entities (BD), virtually no improvement in productivity of an average businesses (VApB and GFCFpB) and an increase in internationalization (FDIpB and $\mathrm{XpB}$ ). The business environment in the Visegrád Group therefore became more outward-oriented between 2004-2014, compared to the 1990s, see (Jiránková and Bolotov, 2015).

\subsection{Business Density (BD)}

The growth of business density in the last ten years was positive in the Visegrád Group countries with the biggest relative number in the Czech Republic (absolute leader, ca. 250 business entities per 1000 economically active) and in Hungary after liberalization of starting a new business and registering property under the government's reform and austerity program of 2008 (approaching 200 business entities per 1000 economically active people) (World Bank, 2015). This increase was mostly interconnected with inflows of FDI and the growing openness of the Visegrád economies; hence new companies were created to adapt to new opportunities. GDP growth and domestic investment, on the contrary, did not play any leading role in the BD's development after 2004. Statistical analysis also points to the importance of the accession to the EU except for Hungary, and, for the Slovak Republic - of the euro adoption, see Figure 1. 


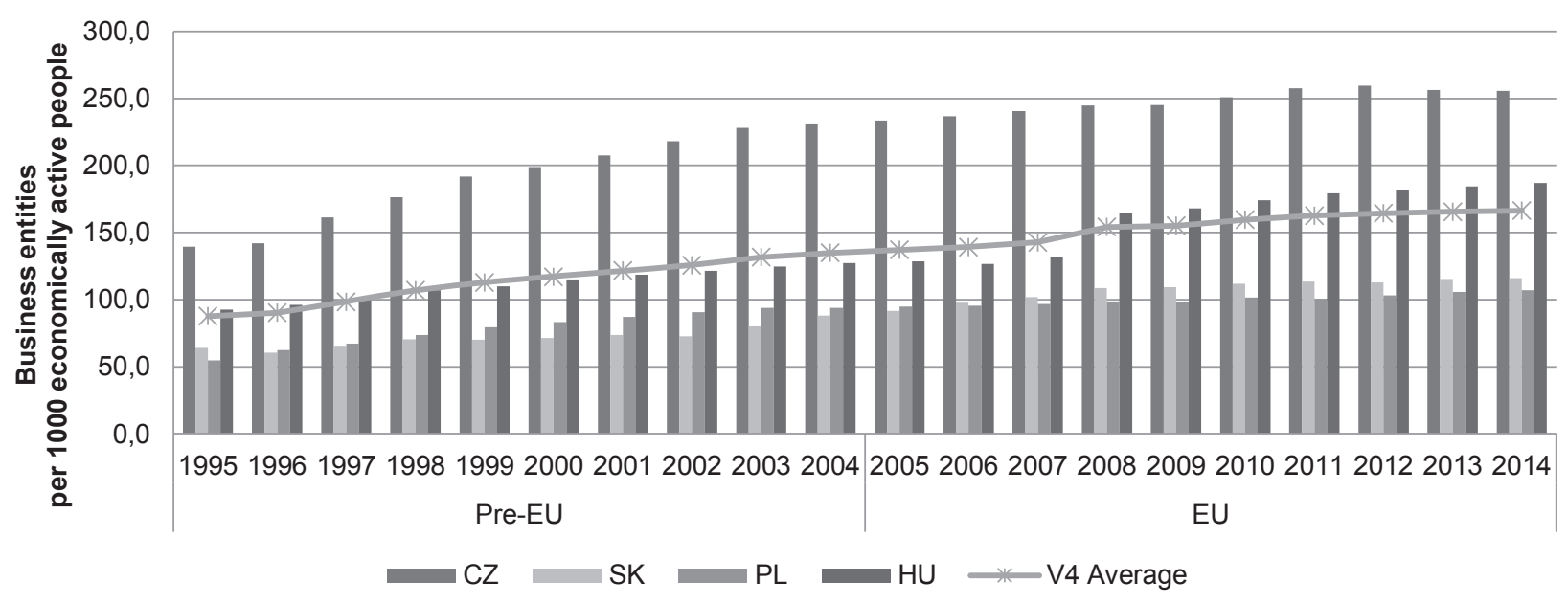

\begin{tabular}{|l|c|c|c|c|c|c|c|}
\hline \multirow{2}{*}{} & \multicolumn{2}{|c|}{ Correlation } & & & & \multicolumn{2}{c|}{ Causality } \\
\cline { 2 - 7 } & VApB & GFCFpB & FDIpB & XpB & $\begin{array}{c}\text { Structural } \\
\text { break }\end{array}$ & RGDPpc & CPL \\
\hline CZ & -0.59 & -0.52 & 0.87 & 0.84 & 2004 & - & - \\
\hline SK & 0.37 & -0.73 & 0.98 & 0.95 & 2004,2008 & - & - \\
\hline PL & 0.40 & 0.45 & 0.85 & 0.84 & 2004 & - & - \\
\hline HU & -0.80 & -0.79 & 0.88 & 0.80 & - & yes & - \\
\hline $\begin{array}{l}\text { Visegrád } \\
\text { Group (V4) }\end{array}$ & -0.07 & -0.63 & 0.96 & 0.94 & - & - & - \\
\hline
\end{tabular}

Note: correlation greater than 0.5 was highlighted

Source: author, national statistical offices' and Eurostat data

\subsection{Value Added per Business Entity (VApB)}

Value added (productivity), measured by GDP per business entity, showed virtually no changes in the last ten years in the Visegrád Group where the highest GDP per business entity was achieved in the Slovak Republic and in Poland (ca. 120,000 EUR and 100,000 EUR per business entity). This development largely corresponded with the one of domestic investment in fixed capital (GFCFpB) but not with the development of the other indicators, and was also statistically influenced by accession to the EU and by the price level, especially for the Czech Republic and for the Visegrád Group's average, see Figure 2. 


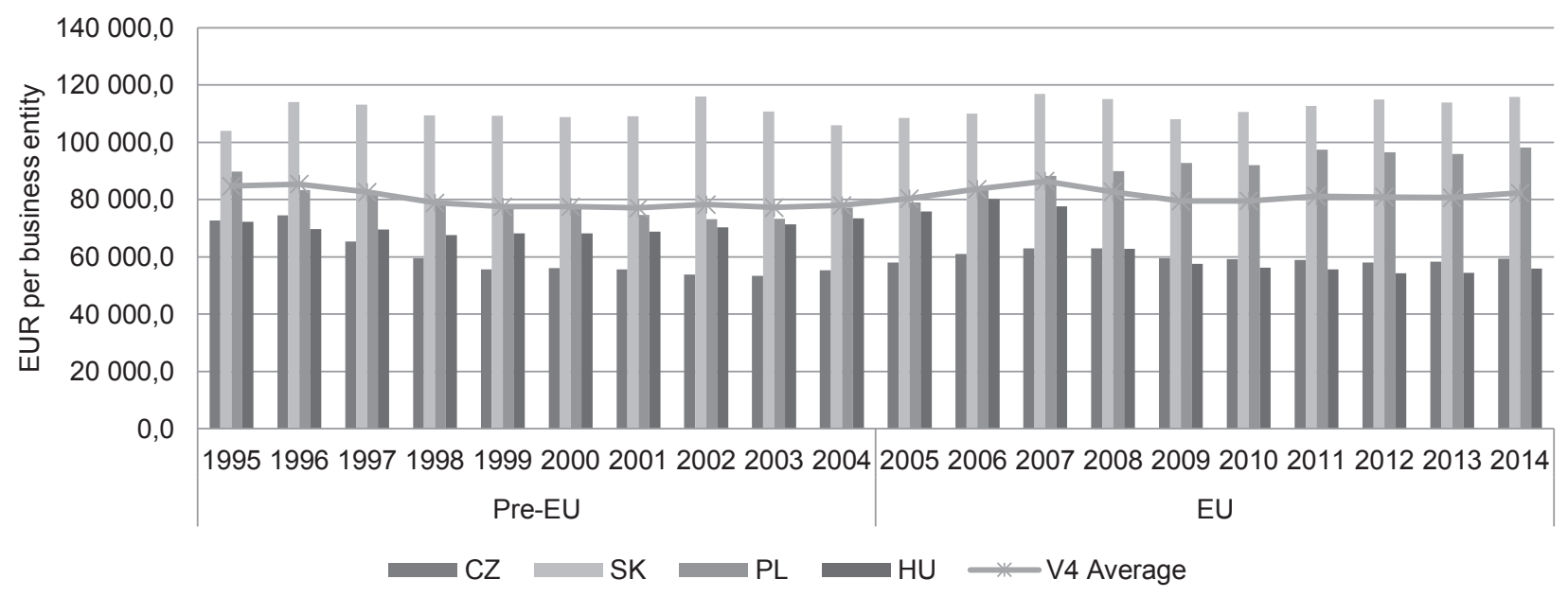

\begin{tabular}{|l|c|c|c|c|c|c|c|}
\hline \multirow{2}{*}{} & \multicolumn{5}{|c|}{ Correlation } & \multicolumn{2}{c|}{ Causality } \\
\cline { 2 - 8 } & BD & GFCFpB & FDIpB & XpB & $\begin{array}{c}\text { Structural } \\
\text { break }\end{array}$ & RGDPpc & CPL \\
\hline CZ & -0.59 & 0.90 & -0.20 & -0.09 & 2004 & - & yes \\
\hline SK & 0.37 & -0.02 & 0.43 & 0.53 & - & - & - \\
\hline PL & 0.40 & 0.84 & 0.81 & 0.82 & 2004 & - & - \\
\hline HU & -0.80 & 0.93 & -0.44 & -0.30 & 2004 & yes & - \\
\hline $\begin{array}{l}\text { Visegrád } \\
\text { Group (V4) }\end{array}$ & -0.07 & 0.54 & 0.16 & 0.24 & 2004 & - & yes \\
\hline
\end{tabular}

Note: correlation greater than 0.5 was highlighted

Source: author, national statistical offices' and Eurostat data

\subsection{Investment in Fixed Capital per Business Entity (GFCFpB)}

Domestic investment in fixed capital per business entity showed a slightly declining trend in the Visegrád Group in the last ten years, especially since the crisis of 2008-2009. The absolute leader in this business performance indicator was the Slovak Republic (ca 25,000 EUR per business entity in 2014). The decline in investment can be explained by the growing number of companies (BD) as well as by the saturation of the Visegrád Group markets. Other influences were almost the same as in the case of VApB (structural break in 2004, the role of real GDP per capita and of the price level in the Czech Republic), see Figure 3. 
Figure 3 | Investment in fixed capital per business entity in the Visegrád Group, long-term development

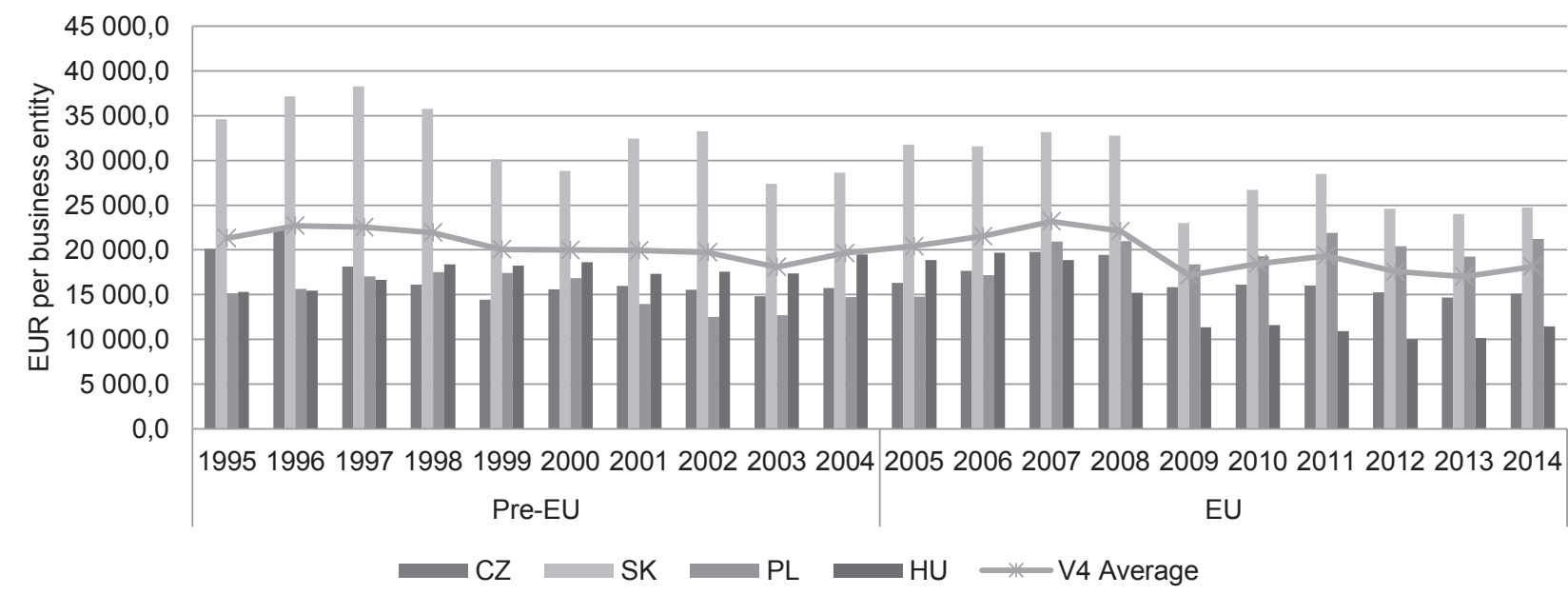

\begin{tabular}{|l|c|c|c|c|c|c|c|}
\hline & \multicolumn{6}{|c|}{ Correlation } & \multicolumn{2}{c|}{ Causality } \\
\cline { 2 - 8 } & BD & VApB & FDIpB & XpB & $\begin{array}{c}\text { Structural } \\
\text { break }\end{array}$ & RGDPpc & CPL \\
\hline CZ & -0.52 & 0.90 & -0.28 & -0.16 & 2004 & yes & yes \\
\hline SK & -0.73 & -0.02 & -0.73 & -0.65 & - & - & - \\
\hline PL & 0.45 & 0.84 & 0.76 & 0.77 & 2004 & - & - \\
\hline HU & -0.79 & 0.93 & -0.51 & -0.35 & 2004 & - & - \\
\hline $\begin{array}{l}\text { Visegrád } \\
\text { Group (V4) }\end{array}$ & -0.63 & 0.54 & -0.54 & -0.42 & 2004,2008 & - & - \\
\hline
\end{tabular}

Note: correlation greater than 0.5 was highlighted

Source: author, national statistical offices' and Eurostat data

\subsection{Inward Foreign Direct Investment Stock per Business Entity (FDIpB)}

The four economies were experiencing an important inflow of FDI per business entity in the last ten years with the Slovak Republic and Hungary leading the Visegrád Group (ca. 80,000 EUR and 50,000 EUR per business entity in 2014), which was slowed down but not reversed by the financial and economic crisis in 2008-2009. This growth of investment stock per business entity correlated with VApB (productivity) and $\mathrm{XpB}$, which suggests that FDI might have improved the position of export industries in the Visegrád Group. Statistically, FDI was also attracted by accession of the countries to the EU, by the Slovak Republic adopting the euro, and in the case of Hungary, by the real GDP per capita and by the price level, see Figure 4. 
Figure 4 | Inward FDI stock per business entity in the Visegrád Group, long-term development

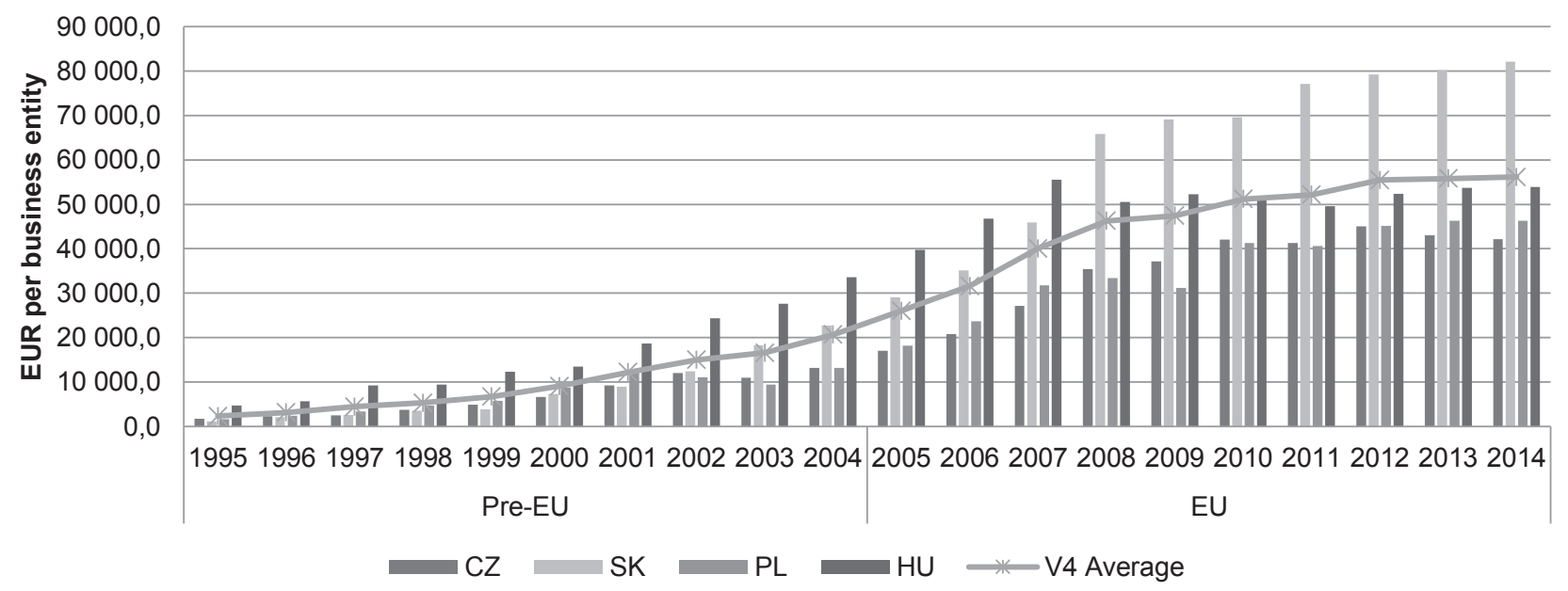

\begin{tabular}{|l|c|c|c|c|c|c|c|}
\hline & \multicolumn{5}{|c|}{ Correlation } & \multicolumn{2}{c|}{ Causality } \\
\cline { 2 - 8 } & BD & VApB & GFCFpB & XpB & $\begin{array}{c}\text { Structural } \\
\text { break }\end{array}$ & RGDPpc & CPL \\
\hline CZ & 0.87 & -0.20 & -0.28 & 0.96 & 2004 & - & - \\
\hline SK & 0.98 & 0.43 & -0.73 & 0.93 & 2004 & - & - \\
\hline PL & 0.85 & 0.81 & 0.76 & 0.99 & 2004 & - & - \\
\hline HU & 0.88 & -0.44 & -0.51 & 0.97 & 2004 & yes & yes \\
\hline $\begin{array}{l}\text { Visegrád } \\
\text { Group (V4) }\end{array}$ & 0.96 & 0.16 & -0.54 & 0.97 & 2004,2008 & - & yes \\
\hline
\end{tabular}

Note: correlation greater than 0.5 was highlighted

Source: author, national statistical offices' and Eurostat data

\subsection{Export of Goods and Services per Business Entity (XpB)}

The development in exports of goods and services per business entity in the Visegrád Group in the last ten years was similar to the one of the inward FDI stock but included a more important correction for the financial and economic crisis in 2009. The Slovak Republic remained the absolute leader among the Visegrád Group with ca. 100,000 EUR per one business entity with the development inside the group being close to homogenous. Statistically, the EU accession, the euro adoption in the Slovak Republic, the price level and exports of goods and services per business entity in the Czech Republic and in the Visegrád Group showed strong relation to this development, see Figure 5. 
Figure 5 | Export of goods and services per business entity in the Visegrád Group, long-term development

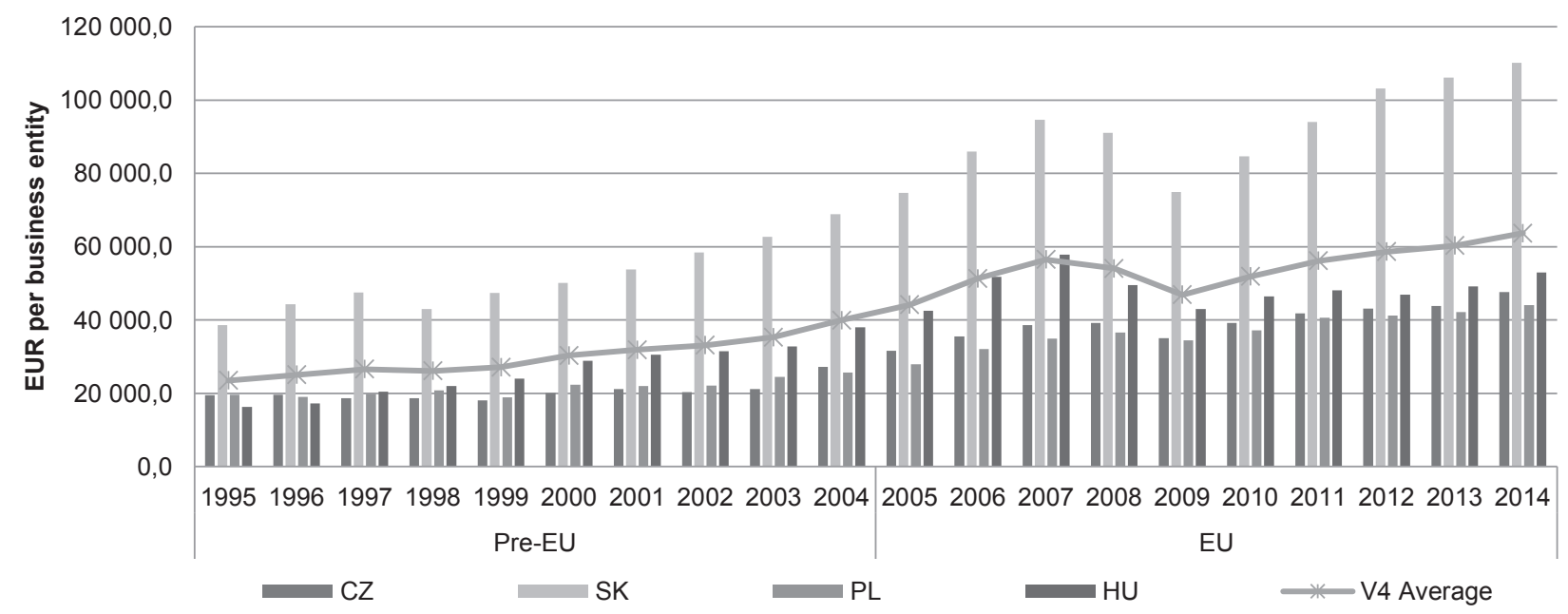

\begin{tabular}{|l|c|c|c|c|c|c|c|}
\hline & \multicolumn{6}{|c|}{ Correlation } & \multicolumn{2}{c|}{ Causality } \\
\cline { 2 - 8 } & BD & VApB & GFCFpB & FDIpB & $\begin{array}{c}\text { Structural } \\
\text { break }\end{array}$ & RGDPpc & CPL \\
\hline CZ & 0.84 & -0.09 & -0.16 & 0.96 & 2004 & - & yes \\
\hline SK & 0.95 & 0.53 & -0.65 & 0.93 & 2008 & - & - \\
\hline PL & 0.84 & 0.82 & 0.77 & 0.99 & 2004 & - & - \\
\hline HU & 0.80 & -0.30 & -0.35 & 0.97 & - & yes & - \\
\hline $\begin{array}{l}\text { Visegrád } \\
\text { Group (V4) }\end{array}$ & 0.94 & 0.24 & -0.42 & 0.97 & 2004,2008 & - & yes \\
\hline
\end{tabular}

Note: correlation greater than 0.5 was highlighted

Source: author, national statistical offices' and Eurostat data

\section{Does the Business Performance in the Visegrád Group Converge?}

Correlation between the four countries for each of the five indicators and its comparison between the EU period and the pre-EU levels is presented in Table 1. Strong positive correlation (greater than 0.5) was registered for all indicators except VApB, out of which only the $\mathrm{BD}, \mathrm{GCFpB}$ and $\mathrm{XpB}$ were showing deepening convergence after 2004, i.e. the business performance in the Visegrád Group was diverging inside the EU (H is rejected).

In the author's opinion, the reasons for diverging business performance in the Visegrád Group can be attributed to several factors: 1) different size of the four economies (Poland on one side and Slovakia on the other); 2) different starting positions (in terms of GDP per capita, technological level, unemployment, etc.); 3) different GDP growth rates in the 2000s; and 4) different macroeconomic policies (attitude toward debt, euro adoption and to business in general); as well as 5) cultural differences (for example, Slavic and Finno-Ugric roots). Since the EU 28 as well as the V4 Group do not have any pro business convergence policy (the closest one is the EU Cohesion Policy), the results should not be surprising - a good example of persisting differences are the value added tax (VAT) levels and bureaucratic requirements in each of the EU countries, which can be illustrated on data of the Heritage Foundation; consult Figure 5. Throughout the 2000s, each V4 country has retained its specific pattern of the economic and business freedom, which supports the quantitative findings. 
Table 1 | Business performance correlation matrix in the Visegrád Group, long-term development

\begin{tabular}{|c|c|c|c|c|c|c|c|c|}
\hline & \multicolumn{4}{|c|}{ Pre-EU } & \multicolumn{4}{|c|}{ EU } \\
\hline & BD-CZ & BD-SK & BD-PL & BD-HU & BD-CZ & BD-SK & BD-PL & BD-HU \\
\hline BD-CZ & & 0.90 & 0.99 & 1.00 & & 0.93 & 0.88 & 0.93 \\
\hline BD-SK & 0.90 & & 0.86 & 0.90 & 0.93 & & 0.88 & 0.96 \\
\hline BD-PL & 0.99 & 0.86 & & 0.99 & 0.88 & 0.88 & & 0.89 \\
\hline BD-HU & 1.00 & 0.90 & 0.99 & & 0.93 & 0.96 & 0.89 & \\
\hline \multirow[t]{2}{*}{ Average } & 0.97 & 0.91 & 0.96 & 0.97 & 0.94 & 0.94 & 0.91 & 0.95 \\
\hline & VApB-CZ & VApB-SK & VApB-PL & VApB-HU & VApB-CZ & VApB-SK & VApB-PL & VApB-HU \\
\hline VApB-CZ & & & 0.91 & & & & -0.25 & \\
\hline \multicolumn{9}{|l|}{ VApB-SK } \\
\hline VApB-PL & 0.91 & & & 0.21 & -0.25 & & & -0.88 \\
\hline VApB-HU & & & 0.21 & & & & -0.88 & \\
\hline \multirow[t]{2}{*}{ Average } & 0.50 & & & & 0.41 & - & - & - \\
\hline & GFCFpB-CZ & GFCFpB-SK & GFCFpB-PL & GFCFpB-HU & GFCFpB-CZ & GFCFpB-SK & GFCFpB-PL & GFCFpB-HU \\
\hline GFCFpB-CZ & & 0.70 & & -0.81 & & 0.93 & & 0.83 \\
\hline GFCFpB-SK & 0.70 & & & -0.63 & 0.93 & & & 0.85 \\
\hline \multicolumn{9}{|l|}{ GFCFpB-PL } \\
\hline GFCFpB-HU & -0.81 & -0.63 & & & 0.83 & 0.85 & & \\
\hline \multirow[t]{2}{*}{ Average } & 0.25 & 0.35 & & -0.08 & 0.72 & 0.73 & & 0.60 \\
\hline & FDIpB-CZ & FDIpB-SK & FDIpB-PL & FDIpB-HU & FDIpB-CZ & FDIpB-SK & FDIpB-PL & FDIpB-HU \\
\hline FDIpB-CZ & & 0.93 & 0.95 & 0.97 & & 0.94 & 0.84 & -0.37 \\
\hline FDIpB-SK & 0.93 & & 0.84 & 0.98 & 0.94 & & 0.80 & -0.35 \\
\hline FDIpB-PL & 0.95 & 0.84 & & 0.90 & 0.84 & 0.80 & & 0.04 \\
\hline FDIpB-HU & 0.97 & 0.98 & 0.90 & & -0.37 & -0.35 & 0.04 & \\
\hline \multirow[t]{2}{*}{ Average } & 0.96 & 0.94 & 0.92 & 0.96 & 0.60 & 0.60 & 0.67 & 0.08 \\
\hline & XpB-CZ & XpB-SK & XpB-PL & XpB-HU & XpB-CZ & XpB-SK & XpB-PL & XpB-HU \\
\hline XpB-CZ & & 0.81 & 0.84 & 0.75 & & 0.97 & 0.98 & 0.85 \\
\hline XpB-SK & 0.81 & & 0.90 & 0.94 & 0.97 & & 0.96 & 0.82 \\
\hline XpB-PL & 0.84 & 0.90 & & 0.91 & 0.98 & 0.96 & & 0.77 \\
\hline XpB-HU & 0.75 & 0.94 & 0.91 & & 0.85 & 0.82 & 0.77 & \\
\hline Average & 0.85 & 0.91 & 0.91 & 0.90 & 0.95 & 0.94 & 0.93 & 0.86 \\
\hline
\end{tabular}

Note: table shows correlation greater than 0.5 , darker colour indicates deeper convergence Source: author, national statistical offices' and Eurostat data. 

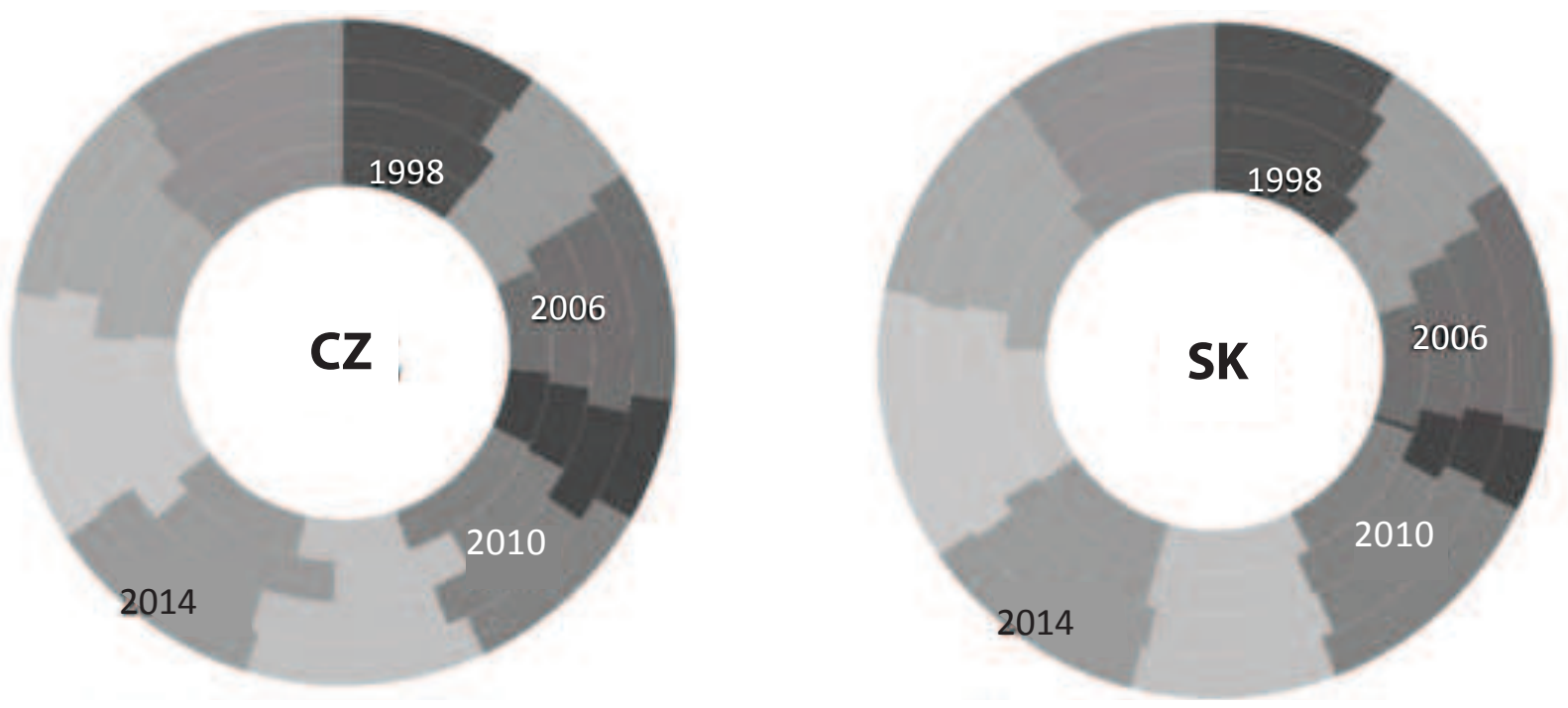

- Property rights index (IEF1)

n Labor freedom index (IEF6)

- Freedom from corruption index (IEF2)

1. Monetary freedom index (IEF7)

a Fiscal freedom index (IEF3)

E Government spending index (IEF4)

II Trade freedom index (IEF8)

E Business freedom index (IEF5)

in Investment freedom index (IEF9)

= Financial freedom index (IEF10)
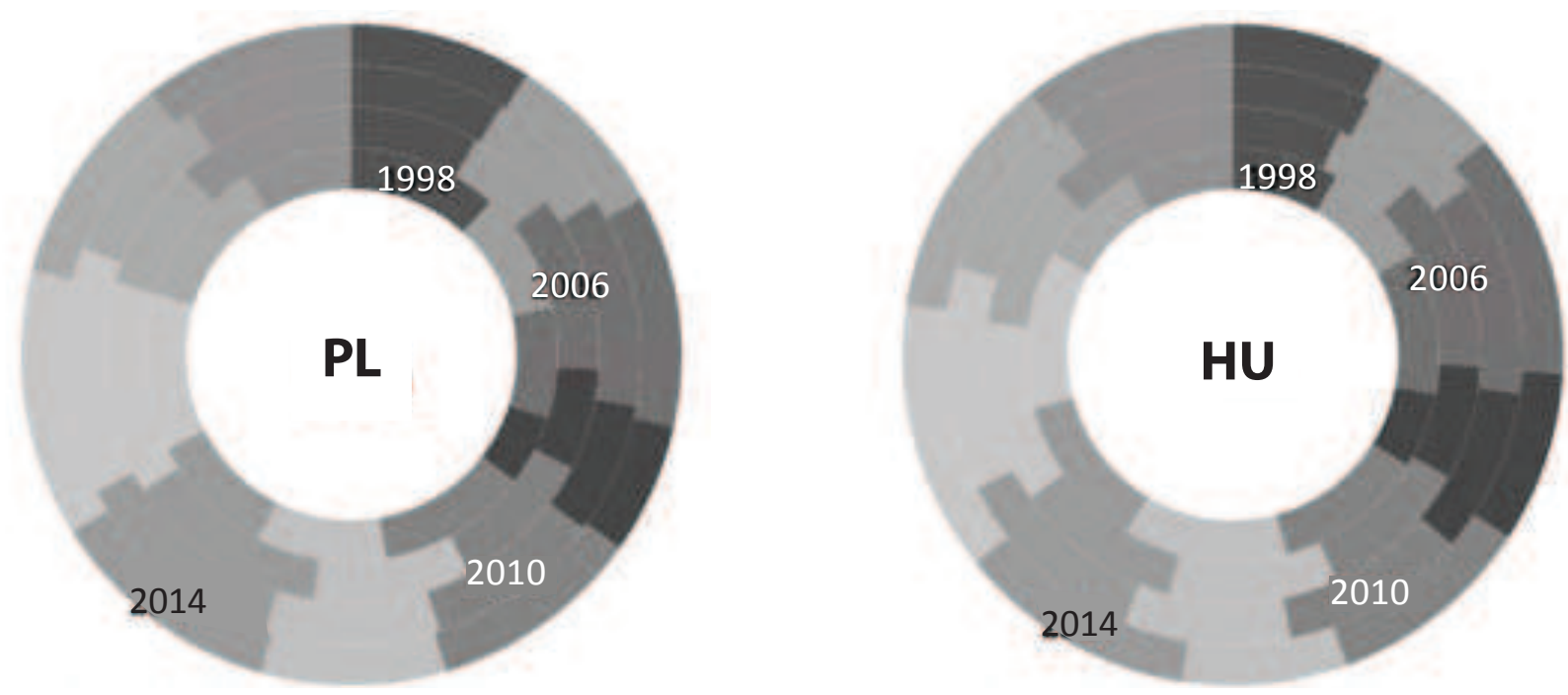

Note: The Index of Economic Freedom is based on 10 quantitative and qualitative factors, grouped into four categories: Rule of Law (property rights, freedom from corruption), Limited Government (fiscal freedom, government spending), Regulatory Efficiency (business freedom, labor freedom, monetary freedom), and Open Markets (trade freedom, investment freedom, financial freedom).

Source: author, Heritage Foundation data

\section{Concluding Remarks}

The paper compared the development of competitiveness and business performance in the Visegrád Group with the help of quantitative analysis. Its main findings are the important role of internationalization in forming of the business environment, its divergence and important regional differences. According to Durendéz and Wach (2014), 50\% of business entities in the Visegrád Group participate in internationalization activities, out 
of which small and medium-sized companies - mostly in the EU and in the neighboring CEEC - utilize less-sophisticated market-entry techniques. Based on the findings of the paper, it is possible to evaluate the hypothesis $(\mathrm{H})$ - the business performance inside the Visegrád Group is converging and is moving towards the EU 28's average - as rejected. The reasons for diverging business performance in the Visegrád Group are most likely more than one; however, apart from country-specific factors, one can point to the fact that both the EU 28 and the Visegrád Group have not yet developed pro business convergence policies, which would ensure same conditions in each member country.

\section{Implications for Managers}

The paper offered an insight into the changes, which occurred in the Visegrád Group after their accession to the European Union in 2004, which can help managers know the group and the EU 28 better. By examining business performance, managers can get a general idea of V4 companies' strengths and weaknesses, as well as the direction of their development. Signs of divergence, for example, point to infeasibility of the one-fits-all approach in the EU 28 and the necessity to adjust to local specifics.

\section{References}

Anisimova, J. A., \& Brenzhagova, N. S. (2012). Financial planning problems of Russian enterprises (for example Close Corporation «ACOM»). Vector of Sciences of TSU: Economics and Management, 11(4), 23-28.

Baláž, P. et al. (2011). Energetická bezpečnost’ v období globalizácie a jej vplyv na konkurencieschopnost'Eú. Bratislava: Sprint dva.

Belás, J., Bartoš, P., Habaník, J., \& Hlawiczka, R. (2014). Significant Attributes of Creation and Development of the Business Environment in the SME Segment. In Proceedings of the 1st International Conference on Finance and Economics 2014. Tomas Bata University in Zlín.

Bluhm, K., Martens, B., \& Trappmann, V. (2011). Business Elites and the Role of Companies in Society: A Comparative Study of Poland, Hungary and Germany. Europe-Asia Studies, 63(6), 1011-1032.

Bolotov, I. (2014a). Obespecheniye konkurentnosposobnosti i blagopriyatnoy predprinimatelskoy sredy na primere g. Praga. In Strategicheskoye planirovaniye razvitiya gorodov i regionov. Pamyati pervogo rektora TGU S. F. Zhilkina (pp. 193-200). Togliatti: Tolyattinskiy gosudarstvennyy universitet.

Bolotov, I. (2014b). Ekonomicheskoye razvitiye Cheshskoy respubliki v 2004-2013 gg. $\mathrm{s}$ aktsentom na privlecheniye inostrannogo kapitala i kachestvo predprinimatelskoy sredy. Actual Problems of Economics and Law, 4(32), 116-125.

Bolotov, I. (2015). The Influencing Factors in the Business Environment of the Visegrád Group in the Last Ten Years and their Comparison to Russia's Experience. Actual Problems of Economics and Law, 3(2015), 17-25.

Bolotov, I., Čajka, R., \& Gajdušková, K. (2013). Economic Development of the EU New Member States: The Impact of the Crisis and the Role of the Single European Currency. Prague: Oeconomica.

Brewster, C., \& Bennett, C. (2010). Perceptions of business cultures in Eastern Europe and their implications for international HRM. International Journal of Human Resource Management, 21(14), 2568-2588. 
Chow, G. C. (1960). Tests of Equality between Sets of Coefficients in Two Linear Regressions. Econometrica, 3(28), 591-605.

Durendéz, A., \& Wach, K. (2014). Patterns of Business Internationalisation in Visegrád Countries In Search for Regional Specifics. Cartagena: Universidad Politécnica de Cartag.

Granger, C. W. J. (1969). Investigating Causal Relations by Econometric Models and Crossspectral Methods. Econometrica, 3(37), 424-438.

Hamplová, E. (2011). Comparison of Business Conditions in the $\mathrm{Cr}$ and $\mathrm{Sr}$ from the Perspective. Aktualne Pohl'ady Na Konkurencieschopnost' a Podnikanie - Nove Vyzvy, 147-152.

Hnát, P., Stuchlíková, Z., \& Bič, J. (2006). Subregionalismus v rámci Evropské unie: projekt IGA 8/05. Prague: Oeconomica.

Jiránková, M., \& Bolotov, I. (2015). Business Environment in the Visegrád Group 2004-2014: A Ten-Year Perspective. Unpublished.

Kalowski, A. (2010). Determinants of Investment of Small- and Medium-Sized Enterprises in Poland. (A. M. Rawani, H. Kettani, \& Z. Lian, Eds.). Liverpool: World Acad Press.

Kinčaková, M. (2013). Theoretical Aspects of Business Environment and Their Practical Application in Slovakia. Aktualne Problemy Podnikovej Sfery, 2013, 234-240.

Kmet', J. (2014). Current Trends in the Business Environment in the Slovak Republic. Aktualne Problemy Podnikovej Sfery, 2014, 203-207.

Machková, H., \& Taušer, J. (2013). Outsourcing jako kapitálově nenáročná forma mezinárodního podnikání. Scientia et Societas, 1(9), 79-86.

Markowicz, I. (2014). Business Demography - Statistical Analysis of Firm Duration. Transformations in Business \& Economics, 13(2B), 801-817.

Nečadová, M., \& Soukup, J. (2013). The Controversial Concept of National Competitiveness and the Results of the Visegrád Group in International Rankings of Competitiveness (2007-2012). Politická ekonomie, 61(5), 583-604.

Němečková, I. (2013). The Role of Salary in Employee Motivation and Retention in the Financial Sector of the Czech Republic in Relation to Herzberg's Two Factor Theory. Politická ekonomie, 61(3), 373-392.

Paličková, I. (2013). Classification of the Competitiveness of the Visegrád Group Countries at the Beginning of the 21st Century. (P. Jedlicka, Ed.). Hradec Kralove: Gaudeamus.

Šebestová, J., Adámek, P., \& Cooney, T. M. (2014). Entrepreneurial Activity as a Driver of Economic Sustainability in the Czech Republic: Lessons from Ireland. Proceedings of the 2nd International Conference on European Integration 2014 (icei 2014), 651-659.

Štěrbová, L. et al. (2013). Mezinárodní obchod ve světové krizi 21. století. Prague: Grada.

Taušer, J., \& Žamberský, P. (2012) Kvalitativní kritéria ve financování veřejných vysokých škol a jejich dopad na Vysokou školu ekonomickou v Praze. Acta Oeconomica Pragensia, 4(20), 74-88.

Urban, S. (2010). The Development of Entrepreneurship in Poland in 1995-2007. (P. Jedlicka, Ed.). Hradec Kralove: Gaudeamus.

Wald, A. (1943). Tests of statistical hypotheses concerning several parameters when the number of observations is large. Transactions of the American Mathematical society, 54(3), 426-482.

World Bank (2015). Doing Business Historical Data. Retrieved May 23, 2015, from http://www.doingbusiness.org/Custom-Query/hungary.

World Economic Forum (2015). The Global Competitiveness Report 2014 - 2015. Retrieved May 23, 2015, from http://www.weforum.org/reports. 
Zuzek, D. K. (2014). Barriers to Development of the Innovation Potential in the Small and Medium-Sized Enterprises in Poland. In G. Mazure (Ed.), Economic Science for Rural Development: Marketing and Sustainable Consumption - Rural Development and Entrepreneurship - Home Economics (pp. 105-111). Jelgava: Latvia Univ Agriculture.

\section{Author}

\section{Ing. Ilya Bolotov, Ph.D., MBA}

Assistant Professor

Department of International Business, Faculty of International Relations,

University of Economics, Prague

Nám. W. Churchilla, 13067 Prague 3, Czech Republic

ilya.bolotov@vse.cz

Acknowledgment

This paper was elaborated in the framework of institutional support of the Faculty of International Relations, University of Economics, Prague, project VŠE IP200040. 